\title{
Diagnostic Value of Monocyte Chemoattractant Protein-1, Soluble Mannose Receptor, Presepsin, and Procalcitonin in Critically Ill Children Admitted with Suspected Sepsis
}

\author{
Noha Hassuna ${ }^{1}$, Ebtesam Elgezawy ${ }^{2}$, Suzan Mousa ${ }^{1}$, Reem AbdelAziz ${ }^{1}$, Reham Ibrahem³ \\ Wafaa Abdel Wahed ${ }^{4}$, Khalid Nasif ${ }^{1}$, and Enas Hefzy ${ }^{4}$ \\ ${ }^{1}$ Minia University Faculty of Medicine \\ ${ }^{2}$ Assiut University Faculty of Medicine \\ ${ }^{3}$ Minia University \\ ${ }^{4}$ Fayoum University Faculty of Medicine
}

January 7, 2021

\begin{abstract}
Background: The differentiation between systemic inflammatory response syndrome (SIRS) and sepsis, which is sometimes difficult, is very important as it determines essential treatment decisions, such as selection, initiation, and duration of antibiotic therapy. Thus we aimed to investigate the diagnostic value of procalcitonin (PCT), monocyte chemoattractant protein-1 (MCP-1), soluble mannose receptor (sMR), presepsin as early biomarkers of pediatric sepsis in comparison to SIRS in a group of severely ill children. Methods: The study included 58 and 24 children diagnosed as having sepsis and SIRS without infection respectively. All the plasma levels of the studied sepsis biomarkers were measured and ROC curves were created for all the tested parameters to discriminate between sepsis and SIRS. Results: The best discriminative performance was for MCP-1 with AUC of 0.996 (0.986-1.005) with sensitivity $98.3 \%$ and specificity $100 \%$. The sMR had the highest sensitivity (100\%), with AUC equals $0.952(.0 .887-1.017)$ and specificity of $91.8 \%$. The cut-off values for PCT, presepsin, sMR, and MCP-1 and were: $2.1 \mathrm{ng} / \mathrm{ml}, 256 \mathrm{pg} / \mathrm{ml}, 24 \mathrm{ng} / \mathrm{ml}$ and $105 \mathrm{pg} / \mathrm{ml}$, respectively. In septic cases, both soluble Mannose Receptor and Procalcitonin have positive correlations with the severity of sepsis (PRISM III), low GCS, ventilatory support, use of inotropic drugs, and mortality rate $(\mathrm{r}=0.950,0.812,0.795,0.732$ and 0.861 respectively) for soluble Mannose Receptor and $(0.536,0.473,0.422,0.305$ and 0.474 respectively) for Procalcitonin. By the logistic regression analysis, the sMR was the only significant predictor of sepsis. Conclusion: The present study has found that sMR, presepsin, and MCP-1 are new biomarkers that can be used to differentiate between sepsis and SIRS in critically-ill children. These findings may direct clinicians in their practical decision-making and complex management of severely-ill children who need much interference in short time.
\end{abstract}

\section{Hosted file}

Hassuna et al 2-1-21.pdf available at https://authorea.com/users/387913/articles/502804diagnostic-value-of-monocyte-chemoattractant-protein-1-soluble-mannose-receptorpresepsin-and-procalcitonin-in-critically-ill-children-admitted-with-suspected-sepsis

\section{Hosted file}

Tables 1.pdf available at https://authorea.com/users/387913/articles/502804-diagnosticvalue-of-monocyte-chemoattractant-protein-1-soluble-mannose-receptor-presepsin-andprocalcitonin-in-critically-ill-children-admitted-with-suspected-sepsis

\section{Hosted file}


Table 2.pdf available at https://authorea.com/users/387913/articles/502804-diagnosticvalue-of-monocyte-chemoattractant-protein-1-soluble-mannose-receptor-presepsin-andprocalcitonin-in-critically-ill-children-admitted-with-suspected-sepsis

\section{Hosted file}

Table 3.pdf available at https://authorea.com/users/387913/articles/502804-diagnosticvalue-of-monocyte-chemoattractant-protein-1-soluble-mannose-receptor-presepsin-andprocalcitonin-in-critically-ill-children-admitted-with-suspected-sepsis

\section{Hosted file}

Table 4.pdf available at https://authorea.com/users/387913/articles/502804-diagnosticvalue-of-monocyte-chemoattractant-protein-1-soluble-mannose-receptor-presepsin-andprocalcitonin-in-critically-ill-children-admitted-with-suspected-sepsis

\section{Hosted file}

Table 5.pdf available at https://authorea.com/users/387913/articles/502804-diagnosticvalue-of-monocyte-chemoattractant-protein-1-soluble-mannose-receptor-presepsin-andprocalcitonin-in-critically-ill-children-admitted-with-suspected-sepsis

A.

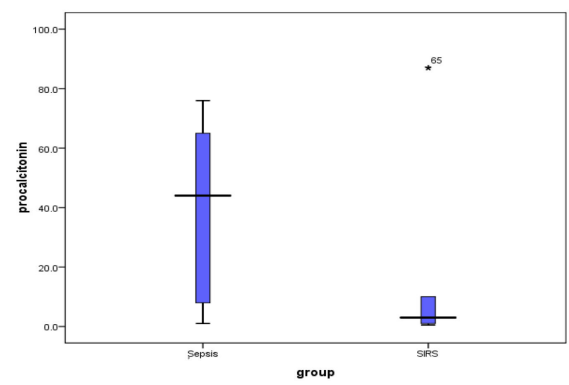

C.

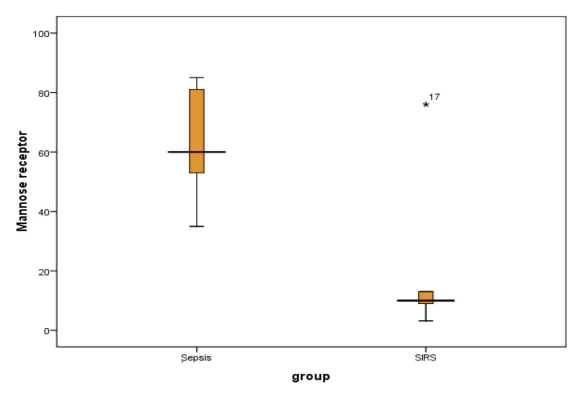

B.

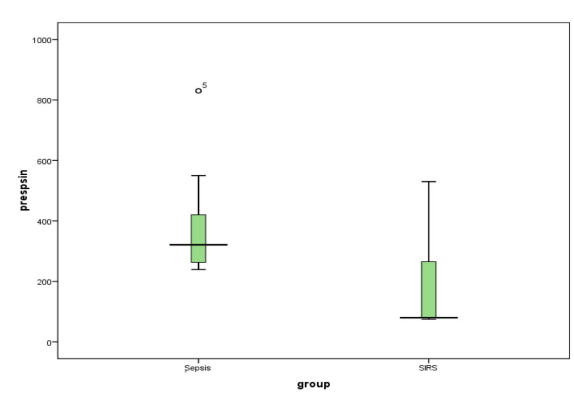

D.

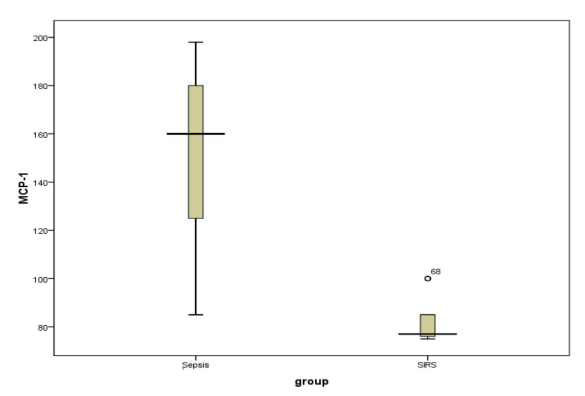




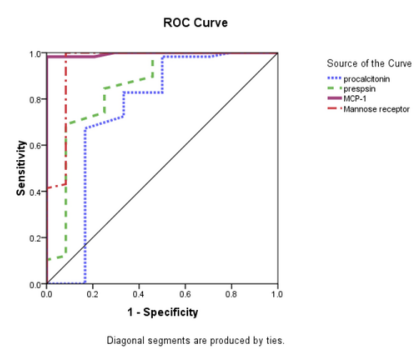

